\title{
Place of Critical Thinking in EFL
}

\author{
Irfan Tosuncuoglu ${ }^{1}$ \\ ${ }^{1}$ Faculty of Letters, Department of English Language and Literature, Karabuk University, Turkey \\ Correspondence: Irfan Tosuncuoglu, Faculty of Letters, Department of English Language and Literature, Karabuk \\ University, Turkey
}

Received: June 10, 2018

Accepted: July 3, 2018

Online Published: July 16, 2018

doi:10.5430/ijhe.v7n4p26

URL: https://doi.org/10.5430/ijhe.v7n4p26

\begin{abstract}
Developing the ability to think critically is vital component of real, meaningful teaching and learning. Critical thinking helps us solve problems, make decisions and reach our goals. Thinking is not a passive but an active process. If students' critical thinking skills are activated, for example while writing, very successful results can be attained. It can be said that critical thinking can be considered in two respects: to achieve a goal and to make a decision. As for teaching, there is very little evidence that students at universities acquire the skills of critical thinking in their learning and teaching activities. In accordance with its important place of in learning and teaching periods, it has been a concept recently highlighted in the field of EFL, like in many other fields of education such as mathematics, history and geography. The skill of critical thinking plays a great role and it has been accepted as an important step in every area of teaching and learning, particularly nowadays due to developments cognition and intelligence. So, in order to understand the awareness of the students for critical thinking, an experiment was performed in the fall of AY 2017-18, with 79 students in Karabuk University, Turkey. In this study, the significance of critical thinking and result of the experiments were discussed in detail, it also shed light on the students' perceptions of it.
\end{abstract}

Keywords: language, teaching, critical thinking, skills, learner

\section{Introduction}

It is clear for everyone that the characteristics most important in differentiating humans from the other species are their thinking skills. However, this skill only is not sufficient by itself. In the 21 st century, humans have to improve their existing thinking ability to handle the world's increasing complexities. One common question instructors have always met is "Where do we begin in seeking to improve human thinking?" (Houghton, 2004). Critical thinking is related to making decisions, and it is desirable behavior. The world is becoming more developed in teaching and all the more complicated, and so the necessity for teaching language has been rapidly increasing for each successive generation in the modern era. The ability of critical thinking is perceived as a very important constituent in every area of teaching and learning for at least the past 60 years. The process of learning a new language is often a difficult activity for the student that undertakes such an important task. It is an activity that naturally includes many different aspects. Each of these aspects in turn can involve diverse features, and each is very significant for the students. Indeed, it is - and has always been - necessary for the study of a language. For example, the student will certainly need to begin by learning the proper pronunciation of words in English when it is being taught as a foreign or a second language. Likewise, the word usage must accompany learning how to combine words into a proper system of phraseology. This process must utilize appropriate rules of grammar, syntax and other areas of concern. On a very basic level, these skills are necessary if the student is going to be able to engage in basic conversational English (Gries, 2008).

\section{Creative Thinking \& Critical Thinking}

Creativity is an ability that might be seen as a factor in learning, but the process of the improvement, involvement and acceleration of creativity might differ from person to person. Creativity has particular features such as multiple focusing, sensitivity to the environment and individuals, rationality, practical thinking, reaching various conclusions, etc. Sometimes, critical thinking is termed "critico-creative". Creative thinking and critical thinking may be accepted as the same concepts. However there are basic differences between these two. Over the past decades, there have been various definitions of critical thinking. For Ennis (1985), critical thinking is "reflective and reasonable thinking that is focused on deciding what to believe or do". On the other hand, Norris (1985) noted critical thinking as "deciding rationally what to do or what to believe". Ragins and Cotton (1999) say: "If students are to function successfully in a 
highly technical society, then they must be equipped with lifelong learning and thinking skills necessary to acquire and process information in an ever changing world". In conclusion, the vital current objective of teaching and learning is to develop thinking abilities of the students as it is basic goal of current methods in in language education.

\subsection{Importance of Critical Thinking}

To develop the ability of learners, thinking critically is a very important component in the contemporary education system. In the modern world, active longitudinal learning, problem solving and empowerment are recognized as the necessary skills to survive (Akdere, 2012). To this end, there is a consensus that critical thinking helps individuals to become active and effective life-long learners, and important problem solvers leading to empowerment (Kincheloe, 2004; Lai, 2009).

In accordance with the vital place of critical thinking in education, critical thinking is a recently highlighted concept in the field of English as a foreign language (EFL). In her paper about critical thinking in EFL, "Language teaching through critical thinking and self-awareness", Üstünlüoğlu (2004) says, states that language teachers have recently focused on the active role of the learner, and this focus has brought cognitive theories of learning to the agenda rather than behaviorism. Similarly, Gough (1991) noted that thinking skills are "crucial for educated persons to cope with a rapidly changing world" and Halpern (2003) took a step further in this idea as he expressed that "critical thinking skills suggest irresistible opportunity for forming and adjusting to change and novelty".

So, critical thinking lies at the very core of language; without it, there can be no concepts that build on each other, as language just becomes the placement of words in a particular syntax without clear logical connections. Critical thinking involves the ability to differentiate the usage of words in various contexts and implicitly understand the language.

\section{Language and the Characteristics of a Critical Thinker}

Lebowitz (2015) notes that in many ways, the relationship between critical thinking skills and language involves the ability of a particular speaker to divide. One of the foremost purposes is simply to perform routine tasks effectively on a basic level. For example, a consumer that wishes to visit a supermarket will generally need to know a basic way to communicate with the employees of the store. If a glance is taken at the descriptions of critical thinking, we might a reach a consensus about the characteristics of a learner who thinks critically. Learners of critical thinking are the persons who investigate, analyze, accept or deny the data, evaluate and come to conclusions, and so on and so forth.

\section{Problem}

In language activities, the teacher presents a topic and various techniques may use in order to teach. Students in general, may have many choices except listening, doing the assignments and giving answers to the teacher, and they may have to follow the rules of grammar and the feedback of their teachers. Educators should consider each learner as an individual and communicate with them openly and empathetically.

On the other hand, concentration on the content created by the imagination of students is important. In fact, teaching should be a lively thing to combine communication and comprehension. Therefore, the ability to take part in effective critical thinking when using the English language is highly dependent upon the user's ability to effectively dissect such linguistic concepts in the first place. In the very fast changing world, it is very important to engage in 'thinking' in every area of the community. For this reason, there is a shift away from classical teaching and learning that aims to transfer knowledge without giving students any time to consider and to digest to a more thought based education that aims to enable students to interpret, analyze, synthesize, and evaluate information. Van Gelder (2005) notes one of the main goals of education, at whatever level, is to help develop general thinking skills, particularly critical thinking abilities. He suggests that the education system and teaching methods need to be improved to grasp this. On the other hand, there are some problems in education in forming critical thinking skills. Paul (1990) says that didactic lectures, extensive coverage of content and mindless drill combine with student passivity to perpetuate the lower order thinking and learning that students have come to associate with educational institutions.

Critical thinking has been an important focus of the instructors/teachers in many countries for many years where there have been lots of changes occurred in education related to the rapid changes of today's world. The need for critical thinkers has increased because the living conditions of people have nowadays become harder and more complex than they used to be. As critical thinking is considered to be a vital skill for the 21 st century, it has become a desirable educational outcome by educators (Lai, 2011). Along the same line, the new regulation in the Turkish National Curriculum (2004) also considers critical thinking as one of the generic skills needing attention in every course. No matter how practical and wise we may be, we may make illogical decisions and arrive at false ideas when we think uncritically. To this end, our aim is to reach a detailed understanding of how students comprehend the matter 
of critical thinking, understand their awareness of it. So, in order to understand the students' awareness about critical thinking, research and an experiment were conducted at Karabuk University for the students of the English Language and Literature.

\section{Research}

The learning and teaching of English as a foreign language is very important for all levels of education in the world as well as in Turkey. In the related literature, it is acknowledged that in order to teach students to think critically, teachers need to be critical thinkers themselves in order to be able to promote this skill in their classes for their students (Ashton, 1988; Kaye \& Ragusa, 1998; Özen, 2013; Williams, 2005). That is, programmed efforts should be spent on teaching critical thinking skills within teacher and student education programs. The main aim of the research is to reach a detailed understanding of how students comprehend the matter of critical thinking and understanding of their knowledge of critical thinking.

In order to understand student awareness of critical thinking, an experiment was conducted in the fall of AY 2017-18. Student participation in the survey was voluntary, and this situation helped us to reach better results. The sample of the research is 79 undergraduate students of English Language and Literature Department, Karabuk University. Students' ages ranged between 18 and 25 years old, and 79 subjects belonging to this study 55 were female and the remaining 24 were male. The following research methods are used in the experiment: literature review, qualitative and quantitative approaches, and a survey. The purposes of the research and the aim of the experiment were explained to the students. Students were also given the option to write their name on an answer sheet or to remain anonymous.

In the study, answers were sought to the following research questions:

1. Do learners have any idea about what critical thinking is?

2. Are the students aware of critical thinking skills?

3. What is the nature of learners' critical thinking strategies?

Also it was hoped that student perception of critical thinking would develop. Experiments were conducted by the author of the research, the students' instructor.

\section{Experiment}

During the experiment, a questionnaire was given to the students in order to evaluate their perceptions about critical thinking in order to promote critical thinking skills of students, and awareness them towards it is tried to be described. The questionnaire consisted of 29 questions in 7 subscales related to their ideas about critical thinking.

\subsection{Subscales}

\section{Thinking Independently (Thinking)}

2. Developing Insight into Egocentricity or Sociocentricity (Developing)

3. Exercising Fair-mindedness (Exercising)

4. Developing Intellectual Humility and Suspending Judgment (Intellectual)

5. Analyzing or Evaluating Arguments, Interpretations, Beliefs or Theories (Analyzing)

6. Generating or Assessing Solutions (Generating)

7. Practicing Socratic Discussion: Clarifying and Questioning Beliefs, Theories or Perspectives (Practicing)

And the results of the students were analyzed by the SPSS program.

\section{GENDER}

\begin{tabular}{llllll}
\hline & & Frequency & percent & $\begin{array}{l}\text { Valid } \\
\text { percent }\end{array}$ & Cumulative percent \\
\hline Valid & Male & 24 & 30,4 & 30,4 & 30,4 \\
& Female & 55 & 69,6 & 69,6 & 100,0 \\
& total & 79 & 100,0 & 100,0 & \\
\hline
\end{tabular}




\section{THINKING}

\begin{tabular}{llllll}
\hline & & Frequency & Percent & Valid Percent & $\begin{array}{l}\text { Cumulative } \\
\text { Percent }\end{array}$ \\
\hline Valid & always & 116 & 24,5 & 29,4 & 29,4 \\
& usually & 195 & 41,1 & 49,4 & 78,7 \\
& sometimes & 81 & 17,1 & 20,5 & 99,2 \\
& never & 3 &, 6 &, 8 & 100,0 \\
& Total & 395 & 83,3 & 100,0 & \\
Missing & System & 79 & 16,7 & & \\
Total & & 474 & 100,0 & & \\
\hline
\end{tabular}

\section{DEVOLOPING}

\begin{tabular}{llllll}
\hline & & & & & Cumulative \\
& & Frequency & Percent & Valid Percent & Percent \\
\hline Valid & always & 107 & 22,6 & 45,3 & 45,3 \\
& usually & 94 & 19,8 & 39,8 & 85,2 \\
& sometimes & 33 & 7,0 & 14,0 & 99,2 \\
& never & 2 &, 4 &, 8 & 100,0 \\
& Total & 236 & 49,8 & 100,0 & \\
Missing & System & 238 & 50,2 & & \\
Total & & 474 & 100,0 & &
\end{tabular}

\section{EXERCISING}

\begin{tabular}{llllll}
\hline & & & & & Cumulative \\
& & Frequency & Percent & Valid Percent & Percent \\
\hline Valid & always & 181 & 38,2 & 38,3 & 38,3 \\
& usually & 199 & 42,0 & 42,1 & 80,3 \\
& sometimes & 82 & 17,3 & 17,3 & 97,7 \\
& never & 11 & 2,3 & 2,3 & 100,0 \\
& Total & 473 & 99,8 & 100,0 & \\
Missing & System & 1 &, 2 & & \\
Total & & 474 & 100,0 & & \\
\hline
\end{tabular}

\section{INTELLECTUAL}

\begin{tabular}{llllll}
\hline & & & & & Cumulative \\
& & Frequency & Percent & Valid Percent & Percent \\
\hline Valid & always & 100 & 21,1 & 42,2 & 42,2 \\
& usually & 97 & 20,5 & 40,9 & 83,1 \\
& sometimes & 32 & 6,8 & 13,5 & 96,6 \\
& never & 8 & 1,7 & 3,4 & 100,0 \\
& Total & 237 & 50,0 & 100,0 & \\
Missing & System & 237 & 50,0 & & \\
Total & & 474 & 100,0 & & \\
\hline
\end{tabular}


ANALYZING

\begin{tabular}{llllll}
\hline & & & & & $\begin{array}{l}\text { Cumulative } \\
\text { Percent }\end{array}$ \\
\hline Valid & always & 44 & 9,3 & 27,8 & 27,8 \\
& usually & 75 & 15,8 & 47,5 & 75,3 \\
& sometimes & 34 & 7,2 & 21,5 & 96,8 \\
& never & 5 & 1,1 & 3,2 & 100,0 \\
& Total & 158 & 33,3 & 100,0 & \\
Missing & System & 316 & 66,7 & & \\
Total & & 474 & 100,0 & &
\end{tabular}

\section{GENERATING}

\begin{tabular}{llllll}
\hline & & Frequency & Percent & Valid Percent & $\begin{array}{l}\text { Cumulative } \\
\text { Percent }\end{array}$ \\
\hline Valid & always & 132 & 27,8 & 33,5 & 33,5 \\
& usually & 181 & 38,2 & 45,9 & 79,4 \\
& sometimes & 72 & 15,2 & 18,3 & 97,7 \\
& never & 9 & 1,9 & 2,3 & 100,0 \\
& Total & 394 & 83,1 & 100,0 & \\
Missing & System & 80 & 16,9 & & \\
Total & & 474 & 100,0 & & \\
\hline
\end{tabular}

\section{PRACTICING}

\begin{tabular}{llllll}
\hline & & Frequency & Percent & Valid Percent & $\begin{array}{l}\text { Cumulative } \\
\text { Percent }\end{array}$ \\
\hline Valid & always & 109 & 23,0 & 27,7 & 27,7 \\
& usually & 188 & 39,7 & 47,7 & 75,4 \\
& sometimes & 87 & 18,4 & 22,1 & 97,5 \\
& never & 10 & 2,1 & 2,5 & 100,0 \\
Missing & Total & 394 & 83,1 & 100,0 & \\
Total & System & 80 & 16,9 & & \\
\hline
\end{tabular}

Depending on the descriptive analysis results of survey data, more than half of the participants were female at $70 \%$. $30 \%$ of the participants were male. The percentages of agreement levels were calculated under seven different subscales.

For the THINKING subscale, $29 \%$ of interviewees said that they "always" agreed with the statements, $49 \%$ of interviewees said that they "usually" agreed with the statements, $21 \%$ of interviewees said that they "sometimes" agreed with the statements and approximately $1 \%$ of the interviewees said that they "never" agreed with the statements under THINKING subscale.

For the DEVOLOPING subscale, $45 \%$ of interviewees said that they "always" agree" with the statements, $40 \%$ of interviewees said that they "usually" agreed with the statements, 14\% of interviewees "sometimes" said that they agreed with the statements and approximately $1 \%$ of the interviewees said that they "never" agreed with the statements.

For the EXERCISING subscale, $38 \%$ of interviewees said that they "always" agreed with the statements, $42 \%$ of interviewees said that they "usually" agreed with the statements, $17 \%$ of interviewees said that they "sometimes" agreed with the statements and approximately $2 \%$ of the interviewees said that they "never" agreed with the statements. 
For the INTELECTUAL subscale, $42 \%$ of interviewees said that they "always" agreed with the statements, $41 \%$ of interviewees said that they "usually" agreed with the statements, $14 \%$ of interviewees said that they "sometimes" agreed with the statements and approximately $3 \%$ of the interviewees said that they "never" agreed with the statements.

For the ANALYZING subscale, $28 \%$ of interviewees said that they "always" agreed with the statements, $48 \%$ of interviewees said that they "usually" agreed with the statements, $22 \%$ of interviewees said that they "sometimes" agreed with the statements and approximately $3 \%$ of the interviewees said that they "never" agreed with the statements.

For the GENERATING subscale, 34\% of interviewees said that they "always" agreed with the statements, $46 \%$ of interviewees said that they "usually" agreed with the statements, $18 \%$ of interviewees said that they "sometimes" agreed with the statements and approximately $2 \%$ of the interviewees said that they "never" agreed with the statements.

For the PRACTICING subscale, $28 \%$ of interviewees said that they "always" agreed with the statements, $48 \%$ of interviewees said that they "usually" agreed with the statements, $22 \%$ of interviewees said that they "sometimes" agreed with the statements and approximately $3 \%$ of the interviewees said that they "never" agreed with the statements.

When we compare the 7 subscales with each other, it can be said the highest ratio for the "always" agreement level belongs to the DEVELOPING subscale with a percent of $45 \%$. For the "usually" level, the highest percentage is observed in THINKING subscale with 49\%. In the PRACTICING subscale, the percentage of the "sometimes" level is the highest, $22 \%$, when compared to other subscales. In addition to this, the ANALYZING subscale has a close percentage to PRACTICING, approximately $22 \%$. The "never" agreement level is similar for all of the subscales and has a very low percentage. For instance, the highest ratio for "never" belongs to PRACTICING with a percentage $3 \%$.

\section{Conclusion/Results}

As the result of experiment, when we compare the four agreement levels the most common answer was "usually". It has the highest agreement ratios in THINKING, EXERCISING, ANALYZING, GENERATING and PRACTICING. For the other two subscales, DEVELOPING and INTELLECTUAL, the most common answer was "always". As expected, the agreement level "never" had the lowest percentage in all of the seven subgroups.

So, it was understood that students' awareness about thinking critically was not at the desirable level. However, being a critical thinker is something totally different from being intelligent or having great knowledge. Critical thinking is about how we put our intelligence and knowledge in use to reach objectives and logical points (Paul, 1990).

Every learner may have an effective ability in critical thinking, and they do not need to agree on anything for granted, so how is the teacher be able to teach critical thinking to learners? Concerning this, an education program for teaching critical thinking might be organized. In order for teachers and instructors to apply critical thinking into their classes effectively, they should first commit themselves to critical thinking and its perception in detail. Since one of the characteristics of a critically thinking teacher is to be a facilitator, a contemporary and modern teacher/instructor should seek a lot of good feedback to reflect on every class taught in order to raise critical thinkers, the future leaders of their countries.

\section{References}

Akdere, N. (2012). Turkish Pre-service Teachers' Critical Thinking Levels, Attitudes and Self-efficacy Beliefs in Teaching for Critical Thinking (Unpublished doctoral dissertation). Middle East Technical University, Ankara, Turkey.

Ashton, P. (1988). Teaching Higher-order Thinking and Content: An Essential Ingredient in Teacher Preparation, Gainesville. FL: University of Florida Press.

Ennis, H.R. (1985). A Logical Basis for Measuring Critical Thinking Skills. Educational Leadership.

Gough, D. (1991). Thinking about Thinking. Retrieved from ERIC database.

Gries, S.T. (2008). Phraseology and Linguistic Theory. Web. Retrieved from http://www.linguistics.ucsb.edu/faculty/stgries/research/2008_STG_PhraseologyLingTheory_Phraseology.pdf. https://doi.org/10.1075/z.139.06gri 
Halpern, D. F. (2003). Thought \& Knowledge: An Introduction to Critical Thinking ( ${ }^{\text {th }}$ Ed.). London: Laurance Erlbaum Associates Publishers.

Houghton, R.S. (2004). Communities Resolving Our Problems (C.R.O.P.): the basic idea: Bloom's Taxonomy Overview. $\quad$ Retrieved $\quad$ March $\quad 12, \quad 2005$ from http://www.ceap.wcu.edu/Houghton/Learner/think/bloomsTaxonomy.html

Kaye, C., Ragusa, G. (1998). Boal's Mirror: Reflections for Teacher Education. Retrieved from ERIC database. (ED419787).

Kincheloe, J. L. (2004). In to the Great Wide Open: Introducing Critical Thinking. In J. L. Kincheloe \& D. Weil (Eds.), Critical Thinking and Learning: An Encyclopedia for Parents and Teachers. Greenwood Press: Westport, Connecticut, London.

Lai, E. R. (2011). Critical thinking: A literature review. Pearson's Research Reports, 6, 40-41.

Lai, Y., K. (2009). Assessing students' Critical Thinking Performance: Urging for measurements using multi-response format. Thinking Skills and Creativity, 4(1), 70-76. https://doi.org/10.1016/j.tsc.2009.02.001

Lebowitz, S. (2015). 9 ways to skip the shallow small talk and have deep conversations. Web. Retrieved from http://www.businessinsider.com/how-to-skip-small-talk-and-have-deep-conversations-2015-12

Norris, S.P. (1985). Synthesis of Research on Critical Thinking. Educational Leadership, 21(8).

Özen, M. (2013). Investigation of pre-service Mathematics teachers' critical thinking processes through statistical and probabilistic knowledge in the context of popular media texts (Unpublished master's thesis). Middle East Technical University, Ankara, Turkey.

Paul, R. (1990). Critical Thinking: What Every Person Needs to Survive in a Rapidly Changing World. Center for Critical Thinking and Moral Critique, Sonoma State University.

Ragins, B.S., Cotton, J.L. (1999). Mentor Functions and Outcomes: A Comparison of Men and Women in Formal and Informal Mentoring Relationships. Journal of Applied Psychology, 84(4), 529-550. https://doi.org/10.1037/0021-9010.84.4.529

Üstünlüoğlu, E. (2004). Language Teaching through Critical Thinking and Self-awareness. Forum, 42, 2-3.

Van Gelder, T. (2005). Teaching Critical Thinking: Some Lessons from Cognitive Science. College Teaching, 53(1), 41-46. https://doi.org/10.3200/CTCH.53.1.41-48.

Williams, R. L. (2005). Targeting Critical Thinking within Teacher Education: The Potential Impact on Society. The Teacher Educator, 40(3), 163-187. https://doi.org/10.1080/08878730509555359 